Samuka Vol 5 No. 1 : hlm 161-168

SAMUKA

Jurnal Samudra Ekonomika

https://ejurnalunsam.id/index.php/jse

\title{
ANALISIS PERAMALAN PRODUKSI MENGGUNAKAN TREND MOMENT PADA KILANG PADI DO'A IBU DIPERLAK KECAMATAN PEUREULAK
}

\author{
Muhammad Rizal ${ }^{1 *},{ }^{2}$ Dewi Rosa Indah, ${ }^{3}$ Rahmi Meutia \\ rizalperlak794@gmail.com \\ dewirosaindah@unsam.ac.id \\ rahmimeutia@unsam.ac.id \\ 1,2,3 Fakultas Ekonomi, Universitas Samudra, Langsa
}

Jalan Prof. Dr. Syarief Thayeb, Meurandeh, Kota Langsa, Aceh 24416

Received: September; Accepted: September 2021; Publishied: September 2021

\begin{abstract}
Abstrak
Perencanaan produksi dilakukan dengan maksud memenuhi permintaan pada tingkat biaya yang minimum. Kegiatan produksi sangat ditentukan oleh ketersediaan bahan baku dan jumlah permintaan. Dengan peramalan produksi maka perusahaan dapat merencanakan produksi baik dalam kualitas maupun kuantitas. Tujuan penelitian ini yaitu untuk menganalisis peramalan produksi menggunakan trend moment pada Kilang Padi Do'a Ibu di Kecamatan Peureulak. Metode analisis data yang digunakan dalam penelitian ini yaitu Trend Moment dengan menggunakan data historis dari satu variabel, dan juga menggunakan indeks musim. Jumlah produksi terendah pada kilang padi Doa Ibu yaitu terjadi pada tahun 2018 yaitu pada bulan Maret sebesar $14.220 \mathrm{~kg}$ dan pada tahun 2019 yaitu pada bulan Mei dengan jumlah produksi beras $16.396 \mathrm{~kg}$. Produksi tertinggi pada tahun 2018 yaitu pada bulan Mei, dimana produksi beras mencapai $27.188 \mathrm{~kg}$ dan produksi beras tertinggi pada tahun 2019 yaitu pada bulan April yang mencapai 28.394 kg. Hasil peramalan menunjukan bahwa produksi beras pada April 2020 mengalami kenaikan menjadi $30.056 \mathrm{~kg}$.
\end{abstract}

\section{Kata Kunci : Peramalan produksi, Trent Moment.}

\begin{abstract}
Production planning is carried out with the aim of meeting demand at a minimum cost level. Production activities are largely determined by the availability of raw materials and the amount of demand. With production forecasting, the company can plan production both in quality and quantity. The purpose of this study is to analyze production forecasting using trend moments at the Do'a Ibu Padi Refinery in Peureulak District. The data analysis method used in this study is Trend Moment using historical data from one variable, and also using the season index. The lowest amount of production at the Doa Ibu rice plant occurred in 2018 in March of 14,220 kg and in 2019 in May with total rice production of 16,396 kg. The highest production in 2018 was in May, where rice production reached 27,188 $\mathrm{kg}$ and the highest rice production in 2017 was in April which reached 28,394 kg. Forecasting results show that rice production in April 2020 increased to 30,056 kg.
\end{abstract}

Keywords: Production Forecasting, Trent Moment. 


\section{PENDAHULUAN}

Peramalan (forecasting) merupakan suatu kegiatan untuk mengetahui apa yang akan terjadi di masa mendatang dengan memperhatikan dan mempertimbangkan data-data yang tersedia dari masa lampau. Peramalan kerap kali digunakan sebagai perencanaan dan operasi kontrol dalam berbagai bidang seperti manajemen produksi, sistem inventori, kontrol kualitas, perencanaan keuangan, dan analisis investasi. Selain itu, peramalan juga digunakan sebagai alat pembuatan keputusan untuk pengeluaran, perencanaan, dan estimasi pertumbuhan di masa yang akan datang.

Metode peramalan adalah sebuah metode yang mampu melakukan analisa terhadap sebuah faktor atau beberapa faktor yang diketahui mempengaruhi terjadinya sebuah peristiwa dengan terdapat waktu tenggang yang panjang antara kebutuhan akan pengetahuan terjadinya sebuah peristiwa di waktu mendatang dengan waktu telah terjadinya peristiwa tersebut dimasa lalu. Apabila metode peramalan ini diterapkan dalam bagian proses perencanaan produksi maka pihak perusahaan akan lebih terbantu dalam penjadwalan produksi, karena metode ini dapat memberikan output terbaik sehingga diharapkan resiko kesalahan yang disebabkan oleh kesalahan perencanaan dapat ditekan seminimal mungkin.

Produksi merupakan kegiatan inti dari suatu perusahaan. Dalam sistem produksi terjadi proses transformasi nilai tambah yang mengubah input bahan mentah menjadi output sebuah produk yang dapat dijual ke pasar. Tujuan dilaksanakannya produksi yaitu untuk memenuhi kebutuhan pasar akan suatu barang dan jasa.

Perencanaan produksi adalah suatu kegiatan yang berkenaan dengan penentuan produk apa dan berapa jumlah yang akan diproduksi oleh suatu perusahaan untuk satu periode mendatang. Perencanaan produksi bertujuan untuk mencapai stabilisasi produksi dan tenaga kerja terhadap fluktuasi permintaan. Penentuan jumlah optimal produk yang akan diproduksi menjadi kunci bagi perencanaan produksi yang tepat. Perencanaan produksi dilakukan dengan maksud memenuhi permintaan pada tingkat biaya yang minimum. Kegiatan produksi sangat ditentukan oleh ketersediaan bahan baku dan jumlah permintaan.

Dengan peramalan produksi maka perusahaan dapat merencanakan produksi baik dalam kualitas maupun kuantitas. Terdapat beberapa metode untuk melakukan peramalan produksi, salah satunya adalah analisis trend moment. Metode trend moment adalah satu metode yang digunakan dalam melakukan peramalan produksi/penjualan, yang nantinya akan dijadikan dasar sebagai penyusunan anggaran penjualan pada tahun berikutnya.

Kilang padi Do'a Ibu merupakan salah satu usaha padi yang terletak di Kecamatan Peureulak Kabupaten Aceh Timur yang bergerak di bidang produksi beras. Perusahaan ini membutuhkan bahan baku, bahan penolong dan berbagai faktor lainnya yang dikombinasikan sedemikian rupa sehingga setelah diolah dalam suatu proses produksi, beras yang dihasilkan diharapkan sesuai dengan standar kualitas yang ditetapkan.

Permasalahan yang ada pada kilang padi Do'a Ibu yaitu belum diterapkannya metode peramalan untuk mengetahui jumlah produksi beras pad periode berikutnya. Dampaknya adalah terdapatnya bahan baku yang menganggur yang tentu akan menimbulkan biaya persediaan bahan baku. tidak tercapainya target produksi beras seperti yang diharapkan dikarenakan kurangnya pengawasan terhadap produksi beras. terjadi fluktuasi produksi beras, dimana produksi terendah pada tahun 2018 terjadi pada bulan Maret dengan produksi sebesar $14.220 \mathrm{~kg}$, dan pada tahun 2019 terjadi pada bulan September yaitu sebesar $16.231 \mathrm{~kg}$. Hal ini terjadi karena belum diterapkannya peramalan produksi sehingga perencanaan jumlah produksi di masa mendatang sulit ditentukan.

Menurut Magfuri (2011:72), produksi adalah mengubah barang agar mempunyai 
kegunaan untuk memenuhi kebutuhan manusia. Jadi produksi merupakan segala kegiatan untuk menciptakan atau menambah guna atas suatu benda yang ditunjukkan untuk memuaskan orang lain melalui pertukaran. Menurut Partadireja (2011:21), setiap proses produksi untuk menghasilkan barang dan jasa dinamai proses produksi karena proses produksi mempunyai landasan teknis yang dalam teori ekonomi disebut fungsi produksi. Menurut Soedarsono (2010:21), yang dimaksud fungsi produksi itu adalah hubungan teknis yang menghubungkan faktor produksi dengan hasil produksi. Sedangkan menurut Kenneth (2010:3) menyatakan bahwa produksi itu merupakan prosedur desain barang dan jasa sebagai output serta sebagai poduk terakhir input element.

Menurut Assauri (2011:184), proses produksi dapat dibedakan atas: Proses produksi yang terputus-putus (intermittent process) : Perencanaan produksi dalam perusahaan pabrik yang mempunyai proses produksi yang terputus-putus, dilakukan berdasarkan jumlah pesanan (order) yang diterima. Oleh karena kegiatan produksi yang dilakukan berdasarkan pesanan (order), maka jumlah produknya biasanya sedikit atau relatif kecil, sehingga perencanaan produksi yang dibuat semata-mata tidak berdasarkan ramalan penjualan (sales forecasting), tetapi terutama didasarkan atas pesanan yang masuk. Perencanaan produksi dibuat untuk menentukan kegiatan produksi yang perlu dilakukan bagi pengerjaan setiap pesanan yang masuk. Proses produksi yang terus-menerus (continuous process) : Perencanaan produksi pada perusahaan yang mempunyai proses produksi yang terus menerus, dilakukan berdasarkan ramalan penjualan. Hal ini karena kegiatan produksi tidak dilakukan berdasarkan pesanan akan tetapi untuk memenuhi pasar dan jumlah yang besar serta berulang-ulang dan telah mempunyai rancangan selama jangka waktu tertentu.

Menurut Gasperzs (2011:87), aktivitas peramalan merupakan suatu fungsi bisnis yang berusaha memperkirakan penjualan dan penggunaan produk sehingga produk-produk itu dapat dibuat dalam kuantitas yang tepat. Dengan demikian peramalan merupakan suatu dugaan terhadap permintaan yang akan datang berdasarkan pada beberapa variabel peramal, sering berdasarkan data deret waktu historis.

Menurut Heizer dan Barry (2012:110), pengertian dari peramalan adalah seni dan ilmu untuk memperkirakan kejadian di masa depan. Hal ini dapat dilakukan dengan melibatkan pengambilan data masa lalu dan menempatkannya ke masa yang akan datang dengan suatu bentuk model matematis. Assauri (2011:215) menjelaskan peramalan merupakan suatu bentuk usaha dengan menerapkan berbagai pendekatan baik kualitatif dan kuantitatif. Salah satu tujuan peramalan untuk memberi kesiapan penuh kepada manajemen perusahaan agar bisa mengetahui berbagai kondisi yang mungkin terjadi di kemudian hari. Menurut Adisaputro dan Yunita (2010:98) peramalan adalah perkiraan mengenai sesuatu yang belum terjadi. Peramalan selalu bertujuan agar ramalan yang dihasilkan mampu meminimumkan pengaruh ketidakpastian yang dihadapi perusahaan.

Menurut Assauri (2011:217), pembagian jenis utama peramalan juga didasarkan atas pembagian jenis perencanaan, yaitu peramalan jangka panjang mencakup tentang penjualan dari produk yang dihasilkan oleh suatu perusahaan selama lima tahun yang akan datang. Ramalan penjualan jangka panjang ini sering mempunyai tujuan-tujuan yang berbeda dengan ramalan penjualan jangka pendek, dan dimaksudkan untuk memungkinkan membuat informasi untuk pengambilan keputusan pada garis-garis kegiatan yang akan memakan waktu untuk pelaksanaannya. Perbedaan-perbedaan dalam tujuan dari ramalan penjualan jangka panjang terlihat dalam isi dan maksudnya, seperti untuk perkembangan produk, perluasan kapasitas dan penanaman modal, yang biasanya terbatas pada perkiraan yang luas tentang jumlah volume penjualan. Sedangkan Peramalan jangka pendek merupakan jenis ramalan yang paling banyak dipergunakan oleh perusahaan pabrik. 
Biasanya ramalan ini mencakup perkiraan tentang penjualan dari produk yang dihasilkan dalam jangka waktu satu tahun atau kurang.

\section{METODE PENELITIAN}

Penelitian ini merupakan bagian dari ilmu manajemen produksi yang mengkaji tentang peramalan penjualan menggunakan analisis trend moment. Penelitian ini dilakukan pada Kilang Padi Do'a Ibu yang beralamat di Kecamatan Peureulak Kabupaten Aceh Timur.

Jenis data yang digunakan dalam penelitian ini adalah data kualitatif dan kuantitatif. Data kualitatif yaitu data yang berupa deskripsi dan data tersebut tidak secara langsung dapat dikuantifikasi. Pengkuantifikasian data kualitatif dilakukan dengan pemberian kode dan kategori (Indrawati, 2015:205). Data kuantitatif adalah data yang berbentuk angka yang kemudian diolah secara matematis (Indrawati, 2015:2016). Data kualitatif dalam penelitian ini berupa gambaran umum Kilang Padi Do'a Ibu, sedangkan data kuantitatif berupa data produksi Kilang Padi Do'a Ibu.

Sumber data dalam penelitian ini yaitu:

1. Data primer, adalah data yang dikumpulkan sendiri oleh perorangan secara langsung dari objek yang diteliti dan untuk kepentingan studi yang bersangkutan (Ardiyanto, 2011:58). Data primer ini diperoleh melalui wawancara dengan pemilik Kilang Padi Do'a Ibu.

2. Data sekunder, adalah data yang dikumpulkan dan disatukan oleh studi-studi sebelumnya atau data yang telah dikumpulkan oleh pihak lain (Ardiyanto, 2011:58). Data sekunder bersumber dari dokumen kilang padi Do'a Ibu serta data lainnya yang mendukung penelitian ini.

Teknik pengumpulan data dalam penelitian ini meliputi:

1. Penelitian Lapangan (field research)

a. Observasi adalah metode pengumpulan data melalui pengamatan kegiatan sehari-hari terhadap objek penelitian (Sugiyono, 2009:203). Observasi dalam penelitian ini dilakukan dengan pengamatan terhadap proses produksi di Kilang Padi Do'a Ibu.

b. Wawancara adalah teknik mengumpulkan data dengan melakukan tanya jawab langsung terhadap objek penelitian (Sugiyono, 2009:194). Wawancara pada penelitian ini dilakukan terhadap pemilik kilang padi Do'a Ibu.

2. Penelitian Kepustakaan (library research)

Adalah teknik pengumpulan data menggunakan studi kepustakaan dan literaturliteratur lainnya yang ada hubungannya dengan penelitian yang dilakukan.

Dalam penerapan metode Trend Moment dapat dilakukan dengan menggunakan data historis dari satu variabel, adapun rumus yang digunakan dalam penyusunan dari metode ini menurut Sugiarto dan Dergibson (2011:97), yaitu :

$\mathrm{Y}=\mathrm{a}+\mathrm{b} \mathrm{X}$

Di mana :

$\mathrm{Y}=$ nilai trend atau variabel yang akan diramalkan

$\mathrm{a}=$ bilangan konstan

$\mathrm{b}=$ slope atau koefisien garis trend

$\mathrm{X}=$ indeks waktu (dimulai dari $0,1,2, \ldots \ldots$ ) 
Untuk mencari nilai a dan b pada rumus di atas, digunakan cara matematis dengan penyelesaiannya menggunakan metode substitusi dan metode eliminasi. Adapun persamaannya menurut Sugiarto dan Dergibson (2011:98), yaitu :

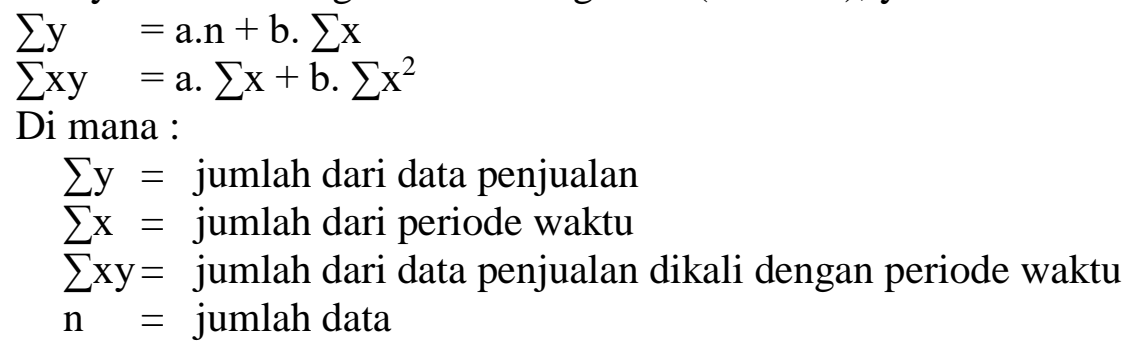

Setelah nilai ramalan yang telah diperoleh dari hasil peramalan dengan metode Trend Moment akan dikoreksi terhadap pengaruh musiman dengan menggunakan indeks musim. Perhitungan indeks musim (Sumaryono, 2014:53) yaitu :

Indeks Musim $=\frac{\text { Rata }- \text { rata permintaan bulan tertentu }}{\text { Rata }- \text { rata permintaan per bulan }}$

Untuk mendapatkan hasil ramalan akhir setelah dipengaruhi oleh indeks musim maka akan menggunakan perhitungan sebagai berikut :

$\mathrm{Y}^{*}=$ Indeks Musim $\times \mathrm{Y}$

Di mana :

$\mathrm{Y}^{*}=$ Hasil ramalan dengan menggunakan metode Trend Moment yang telah dipengaruhi oleh indeks musim

$\mathrm{Y}=$ Hasil ramalan dengan menggunakan Trend Moment

\section{HASIL DAN PEMBAHASAN}

Hasil

Berdasarkan data yang diberikan oleh pihak kilang padi Do'a Ibu diperoleh data produksi beras. Dari data tersebut maka dapat diramalkan produksi beras menggunakan metode trend moment. Analisis peramalan dengan metode trend moment dilakukan dengan menggunakan data historis dari satu variabel.

Tabel 1. Analisis Peramalan Produksi Beras

\begin{tabular}{lcccc}
\hline \multicolumn{1}{c}{ Bulan/Tahun } & $\begin{array}{c}\text { Produksi } \\
(\mathbf{y})\end{array}$ & $\begin{array}{c}\text { Waktu } \\
(\mathbf{x})\end{array}$ & $\mathbf{x . y}$ & $\mathbf{x}^{\mathbf{2}}$ \\
\hline Januari & 14.983 & 0 & 0 & 0 \\
Februari & 15.671 & 1 & 15671 & 1 \\
Maret & 14.220 & 2 & 28440 & 4 \\
April & 17.092 & 3 & 51276 & 9 \\
Mei & 27.188 & 4 & 108752 & 16 \\
Juni & 18.772 & 5 & 93860 & 25 \\
Juli & 19.201 & 6 & 115206 & 36 \\
Agustus & 22.199 & 7 & 155393 & 49 \\
September & 17.281 & 8 & 138248 & 64 \\
\hline
\end{tabular}




\begin{tabular}{|c|c|c|c|c|}
\hline Oktober & 16.930 & 9 & 152370 & 81 \\
\hline November & 18.203 & 10 & 182030 & 100 \\
\hline Desember & 16.688 & 11 & 183568 & 121 \\
\hline Januari & 24.320 & 12 & 291840 & 144 \\
\hline Februari & 23.011 & 13 & 299143 & 169 \\
\hline Maret & 27.883 & 14 & 390362 & 196 \\
\hline April & 28.394 & 15 & 425910 & 225 \\
\hline Mei & 16.396 & 16 & 262336 & 256 \\
\hline Juni & 17.713 & 17 & 301121 & 289 \\
\hline Juli & 19.892 & 18 & 358056 & 324 \\
\hline Agustus & 20.288 & 19 & 385472 & 361 \\
\hline September & 16.231 & 20 & 324620 & 400 \\
\hline Oktober & 19.286 & 21 & 405006 & 441 \\
\hline November & 20.659 & 22 & 454498 & 484 \\
\hline Desember & 19.283 & 23 & 443509 & 529 \\
\hline Jumlah $\left(\sum\right)$ & 486767 & 276 & 5566687 & 4324 \\
\hline Rata-rata perbulan & 19.471 & & & \\
\hline
\end{tabular}

Sumber: data diolah (2019)

Berdasarkan Tabel 1 maka untuk memperoleh nilai a dan $\mathrm{b}$ yaitu dengan cara sebagai berikut:

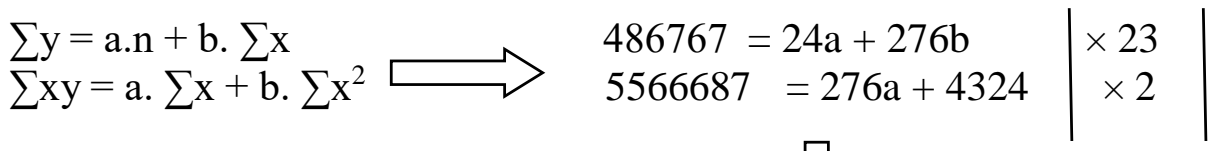

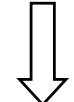

$$
\begin{aligned}
& 11195641=552 \mathrm{a}+6348 \mathrm{~b} \\
& 11133374=552 \mathrm{a}+8648 \mathrm{~b} \\
& 62267=-2300 \mathrm{~b} \\
& \mathrm{~b}=\frac{62267}{2300} \\
& \mathrm{~b}=27,07
\end{aligned}
$$

Perhitungan untuk mencari nilai a yaitu:

$$
\begin{aligned}
486767 & =24 a+276 b \\
486767 & =24 a+276(27,07) \\
486767 & =24 a+7471,32 \\
24 a & =486767-7471,32 \\
24 a & =479295,68 \\
a & =479295,68
\end{aligned}
$$




$$
\mathrm{a} \quad=19970,65
$$

Setelah diperoleh nilai a dan b maka diformulasikan ke dalam rumus trend moment yaitu:

$$
\begin{aligned}
& \mathrm{Y}=\mathrm{a}+\mathrm{bx} \longrightarrow \quad \begin{array}{l}
\mathrm{Y}=19970,65+27,07(\mathrm{x}) \\
\mathrm{Y}=19970,65+27,07(28) \\
\mathrm{Y}=20728,61
\end{array}
\end{aligned}
$$

Setelah itu peramalan yang diperoleh dari nilai trend di atas akan dihitung menggunakan indeks musim. Berdasarkan rumus indeks musim maka:

$$
\text { Indeks Musim }=\frac{\text { Rata }- \text { rata permintaan bulan tertentu }}{\text { Rata }- \text { rata permintaan per bulan }}=\frac{28.394}{19.471}=1,45
$$

Hasil dari ramalah akhir setelah dipengaruhi oleh indeks musim maka akan menggunakan perhitungan sebagai berikut:

$$
\begin{aligned}
\mathrm{Y}^{*} & =\text { Indeks Musim } \times \mathrm{Y} \\
\mathrm{Y}^{*} & =1,45 \times 20728,61 \\
& =30056,48
\end{aligned}
$$

\section{Pembahasan}

Setelah mendapatkan nilai akhir dari peramalan dengan menggunakan metode Trend Moment dengan dipengaruhi indeks musim yakni 30056,48 maka nilai tersebut akan dibulatkan. Jadi hasil yang diperoleh untuk peramalan produksi beras pada Kilang Padi Do'a Ibu untuk bulan April 2020 yaitu sebesar $30.056 \mathrm{~kg}$.

Menurut Adisaputro dan Yunita (2010:98) peramalan adalah perkiraan mengenai sesuatu yang belum terjadi. Peramalan selalu bertujuan agar ramalan yang dihasilkan mampu meminimumkan pengaruh ketidakpastian yang dihadapi perusahaan Peramalan atau forecasting yaitu aktivitas memprediksi atau memperkirakan apa yang akan terjadi di masa yang akan datang dengan waktu yang relatif lama. Peramalan (forecasting) adalah suatu teknik analisa perhitungan yang dilakukan dengan pendekatan kualitatif ataupun keuantitatif untuk melakukan perkiraan peristiwa pada masa depan dengan penggunaan referensi data-data pada masa lalu. Peramalan memiliki tujuan untuk memprediksi prospek ekonomi dan aktivitas usaha dan juga pengaruh lingkungan kepada prospek tersebut. Peramalan sebenarnya upaya untuk memperkecil resiko yang timbul akibat pengambilan keputusan dalam suatu perencanaan produksi. Semakin besar upaya yang dikeluarkan tentu resiko yang dapat dihindari semakin besar pula. Namun upaya memperkecil risiko tersebut dibatasi oleh biaya yang dikeluarkan akibat mengupayakan hal tersebut, (Fiati, 2009:77).

Pada penelitian sebelumnya yang dilakukan oleh Soma (2012) menjelaskan bahwa metode trend moment ini digunakan untuk dapat mengatasi permasalahan yaitu peramalan penjualan. Begitu juga penelitian yang dilakukan oleh Sumaryono (2014) yang mengatakan bahwa dengan menggunakan metode ramalan Trend Moment dan merancang aplikasi peramalan penjualan/produksi untuk mengatasi kerugian dan tidak tercapainya target perusahaan. Samahalnya dengan penelitian yang dilakukan oleh Muthia (2012), perusahaan mengalami peningkatan penjualan dibandingkan dengan penjualan motor pada tahun sebelumnya. Peneliti menganalisis hasil ramalan penjualan motor dengan menggunakan metode ramalan Trend Moment dan merancang aplikasi peramalan penjualan motor dengan menggunakan metode Trend Moment untuk mengatasi kerugian yang akan dihadapi perusahaan. 
Dalam hal peramalan produksi pada kilang padi Do'a Ibu dilakukan agar kapasitas produksi yang direncanakan tepat sasaran, artinya tidak ada hasil produksi yang tidak bisa dijual ke pasar. Setelah melakukan analisis perencanaan produksi menggunakan trend moment maka diketahui bahwa produksi beras bulan April 2020 mengalami kenaikan. Hal ini dapat dibandingkan dengan produksi pada April 2019 yaitu 128.394 kg. Sedangkan dari peramalan penjualan menggunakan analisis trend moment diketahui produksi beras pada April 2020 mengalami kenaikan menjadi $30.056 \mathrm{~kg}$.

\section{KESIMPULAN}

Dari analisis data dan pembahasan maka dapat ditarik kesimpulan sebagai berikut:

1. Jumlah produksi terendah pada kilang padi Doa Ibu yaitu terjadi pada tahun 2018 yaitu pada bulan Maret sebesar $14.220 \mathrm{~kg}$ dan pada tahun 2019 yaitu pada bulan Mei dengan jumlah produksi beras $16.396 \mathrm{~kg}$.

2. Produksi tertinggi pada tahun 2018 yaitu pada bulan Mei, dimana produksi beras mencapai $27.188 \mathrm{~kg}$ dan produksi beras tertinggi pada tahun 2019 yaitu pada bulan April yang mencapai $28.394 \mathrm{~kg}$

3. Hasil peramalan menunjukan bahwa produksi beras pada April 2020 mengalami kenaikan menjadi $30.056 \mathrm{~kg}$.

\section{REFERENSI}

Adisaputro, Gunawan dan Yunita Anggaraini. 2010. Anggaran Bisnis, Yogyakarta:UPP STIM YKPN

Ardianto, Elvinaro. 2011. Metodologi Penelitian Untuk Public Relation : Kuantitatif dan Kualitatif.

Assauri, Sofyan.2011. Manajemen Produksi dan Operasi. Jakarta: FE UI.

Fiati, R. 2009. Sistem Pendukung Peramalan Penjualan Barang, Yogyakarta: Universitas Gadjah Mada.

Gaspersz, Vincent. 2011. Total Quality Management. Jakarta: Gramedia Pustaka Utama. Heizer, Jay dan Barry Render. 2012. Manajemen Operasi. Jakarta: Salemba Empat.

Indrawati. 2015. Metode Penelitian Manajemen dan Bisnis Konvergensi. Bandung: Teknologi Komunikasi dan Informasi.

Kenneth, Loudon. 2010. Manajemen produksi dan Operasi. Jakarta: Salemba Empat. Magfuri. 2011. Manajemen produksi dan Operasi. Bandung: Alfabeta.

Makridakis, S. 2008. Metode Peramalan Untuk Manajemen. Jakarta: Binarupa Akasara. Partadireja, Ace. 2011. Manajemen Produksi. Edisi ketiga. Jakarta: Ghalia Indonesia.

Soedarsono. 2010. Manajemen Operasional. Yogyakarta: Liberty

Soma, Arief. 2012. Sistem Pendukung Peramalan Penjualan batik di Pekalongan dengan Metode Trend Moment. Majalah Ilmiah. Vol 7 No 1 Hal 1-5.

Sugiono. 2009. Metode Penelitian Pendidikan Pendekatan Kuantitatif, Kualitatif dan R\&D. Bandung; Alfabeta.

Sugiarto dan Dergibson, S. 2011. Metode Statistika Untuk Bisnis dan Ekonomi. Jakarta: Gramedia Pustaka Utama.

Sumaryono, Roy. 2014. Penerapan Metode Trend Moment dalam Forecast Penjualan Beton Readymix di PT. X mojokerto. Jurnal Media Mahardika. Vol 13 No 1 Hal 51-57. 